\title{
Design Activities as a Literation for Introduction to Horticulture Agriculture for Children Aged 5 - 12 Years Old
}

\author{
Lintang Aziz Pinastiti 1,*, Riama Maslan Sihombing ${ }^{2}$, Irfansyah Irfansyah ${ }^{3}$ \\ ${ }^{1}$ Institut Teknologi Bandung, Indonesia \\ ${ }^{2}$ Institut Teknologi Bandung, Indonesia \\ ${ }^{3}$ Institut Teknologi Bandung, Indonesia \\ Corresponding email: lintangazizpinastiti@students.itb.ac.id
}

\begin{abstract}
The agricultural sector in its environment with a sector that is important in development is not spared from problems, there is a shift in job opportunities in agricultural land. Agriculture is very important for human survival, every day what we consume is the result of agriculture such as rice that we eat every day as staple food, vegetable side dishes as side dishes such as tomatoes, mustard greens, spinach, and many more. One of the important agricultural cultivation is Horticulture. Horticulture comes from the word hortus which means garden and colere which is to grow. They are very familiar with daily food so that children not only know how vegetables and fruit can be eaten, children also know how to plant them and cultivate them. Introducing the world of agriculture from an early age, one of which is the introduction. Giving children is the bud of the nation, the need to instill them to love their environment. For this reason, a literacy design for the introduction of horticulture agriculture is made for children aged 5-12 years (kindergarten and elementary school age). This design is made with the design of the Activity Book in which children will learn and at the same time carry out agricultural activities so that children can practice directly. This design is expected to be able to fill children's spare time at home but provide more knowledge about horticultural agriculture so that agriculture is important for survival and agriculture is also a proper work choice
\end{abstract}

Keywords: Agriculture, Horticulture, Literacy, Activity Book, Creative Book

\section{INTRODUCTION}

Indonesia is a tropical country that has the richest biodiversity in the world. Solar energy and good rainfall support agriculture in Indonesia to produce every year. LIPI noted that Indonesia's biological wealth includes 6000 species of flowering plants, wild and cultivated, used for food, clothing, and medicines. Agriculture is an activity that uses biological resources by humans to produce the food we eat every day, industrial raw materials, or energy sources, and to manage their environment. Agriculture is essential for human survival. Every day what we consume is the result of agriculture, such as rice which we eat as a staple food, side dishes of vegetables as side dishes such as tomatoes, mustard greens, spinach, kale and many more. "So far, young people have not been interested in farming because it is outdated, dirty, and so on. But actually, there are challenges that young people have to face in farming. This young group is hampered in getting access to land Becoming a Young Farmers: Yong People's Pathways into Farming in Four Countries" conducted in Indonesia, China, India, and Canada. The agricultural sector has a significant influence in supporting food security, national stability, and generating foreign exchange. Interview with Mr Budi Widodo, Head of the Horticulture Section of the Department of Agriculture and Horticulture, Malang Regency, explained that one of the lack of interest of the younger generation in agriculture is the internal factor, namely that there are still many young people who do not understand how to view agriculture. From external factors, agriculture has not been widely used with adequate technology. So that it is still lacking with other countries, and the last factor is the increasingly 
narrow land ownership factor so that there is also a lack of media and places for cultivation. Cultivating plants that are useful for human survival, for example, vegetable foods are eaten daily, tomatoes, long beans, spinach and fruits such as apples, oranges and other fruits are called horticultural products. Vegetables and fruits are agricultural products called Horticulture. Horticulture comes from the word hortus, which means garden and colere, which means grow. So it is better to introduce agriculture with horticultural cultivation from the child's age. Because children are the next generation of the nation for agricultural cultivation and food security. Childhood is a crucial period in forming physical skills, intelligence and character. Children will carry out more diverse activities in physical skills because muscle mass has increased. In intelligence, children will actively find out something new and what they face. From various experiences, they can then be processed to form character and moral values. All this determines how humans will develop and behave if the introduction of agriculture is done since childhood. At an early age, literacy is critical given to children to communicate thoughts in spoken language, understand information conveyed by others orally, understand written statements, recognize the names of letters and sound letters [1]. Because PISA (Program for International Student Assessment) shows a low level of literacy in Indonesia compared to other countries globally, this is the result of research on 72 countries; Indonesia ranks 62 out of 70 countries. Visual literacy is defined as the ability to understand and use images, including thinking, learning, and expressing oneself in terms of ideas. Dan Riddle also explained that visual literacy is the ability to interpret, use and create visual media, which improves the process of making decisions and communication and learning [2]. Visual literacy is critical.

According to Barbara Seuling in the book How to Write Children's Book, at the age of 5, she has begun to understand reading, understand, and understand it and can write well. Entering the school-age of 5-12 years is called the intellectual period. The skills possessed are varied, children's interests begin to be owned. Children will like various activities that will be useful in their future development. Therefore this design is intended for children aged 5-12 years. Literacy activities that can be predictors are active exploration and participation. Then it is necessary to introduce media to horticultural agriculture for children. In this pandemic, children are busy with gadgets and constantly looking at the internet. According to a 2010 study, Bristol University revealed that the dangers of gadgets in children could increase the risk of depression, anxiety disorders, attention disorders, autism, bipolar disorder, psychosis, and other problems.

\subsection{Picture books and age-appropriate reading}

Picture books are books that contain illustrated or bland content guides and are accompanied by text. Picture books are usually shaped like story books aimed at children aged 4-15 years. Learning media using picture books will help children understand information faster and will add to the child's experience. Rahadi explains that pictures or illustrations made in books will also facilitate the message to be conveyed to the reader [4]. According to John Shelley, illustrator and editor of children's books at the organization Words and Pictures, at the website wordsandpics.org (2013). Fundamental technical steps in the design of children's books that need to be considered.

\section{a. Children's Book}

Text and illustrations In various forms, children's books are divided into two types: storybooks, which have text that tells the whole story and can be digested without pictures, and picture books, which have text and pictures. Strung together to tell a story.

\section{b. Storyboard}

Storyboard, An illustrator's first step in designing a children's book is to create a storyboard on a piece of paper and provide an overview of the book's contents in grids of thumbnails. In this way, the illustrator can sketch a rough design for each page, plot the storyline from page to page, divide the content of the text, define dramatic points, and set the rhythm of the illustration image. Sketches as small as a thumbnail grid are easier to correct and redraw.

\section{c. Layout}

Each book and illustrator has varied styles, compositions, and designs. However, some points are commonly found in a children's book, namely boxed, vignette, full-bleed, and spot.

\section{d. Size}

Illustration A small image on a page surrounded by white space will focus on details and create a quiet intimacy or become a little picture of a drama that will unfold. Some books start with small pictures and then gradually become full-page illustrations once they climax. It can also be the opposite, from big to small. Another function of small images is to divide the series of actions into more detail. By dividing the action stages in the form of vignettes or spots on a page, the sequence of time and movement will be seen.

\section{e. Rhythm and pattern}

A picture book usually has a pattern or structure that flows through the entire story, with a flowing rhythm and dynamic and jerky pages in critical sections. These patterns and rhythms are manifested both with text and illustrations. 


\section{f. Typography}

The use of typography in children's books must pay attention to the ease of readability for children. Several types of letters and provisions are recommended for child readers, including sans serif fonts that will be easier to read, limit the number of font types, and sufficient size

\section{g. illustration}

The National Museum of Illustration explains that illustration is a forum for our social life and has become a cultural history that occurred in the country [5]. Therefore, illustration can be translated as an art form that is timeless and significant. Another definition, according to him, illustration is the art of drawing used to explain a goal and purpose through visual means. In the book The Fundamentals of Illustration, Zeegen argues that illustration is a picture of the imagination poured into a medium and embedded in one's memory because it tightly binds an individual's historical moment with that period [6].

The thought process is closely related to a person's cognitive development. Cognitive is one aspect of human development related to understanding (knowledge), namely all psychological processes related to how individuals learn and study the environment [7]. It is suggested that relevant book reading for those stages is as follows:

a. Sensory-motor stage (0-2 years): Board Book, Activity, Busy Book, Build early skills

b. Preoperational Stage (2-7 years): Picture Book, Coloring \& Activity Book

c. Concrete operational stage (7-11 years): Fantasy, Fairy Tale, Manga, Series, Joke Book, Science Activities

d. Formal operation stage (11-15 years): Horror, Novel, Science Book

\subsection{Agriculture for Children}

The definition of horticulture in terms of the Big Indonesian Dictionary has an understanding which means the cultivation and maintenance of flower, fruit and vegetable gardens. The word Horticulture (Horticulture) comes from the Latin "hortus" which means garden and "colere" which means to cultivate so that horticulture is defined as cultivating plants in the garden. Literally, horticulture means the science that makes the cultivation of garden plants the focus of the lesson. People who are experts in horticulture (horticultural experts) are known as horticulturists [8].

Horticulture has various benefits as mentioned by the Head of the Horticulture Section of the Department of Agriculture and Horticulture Kab. Malang, Mr. Budi
Widodo S.P explained that the benefits of Horticulture include:

a. For energy needs

Horticultural crops will be very useful to meet the energy needs of many people because horticulture is a type of plant cultivation in a simpler way and can meet the consumption needs of many people.

\section{b. For Vitamins}

Vitamin needs are also one of the daily needs that are very important for the community. With the presence of fruit and vegetables from horticultural products, the individual's need for vitamin intake will also be maintained.

\section{c. For mineral needs}

d. Minerals from organic plants play an important role in maintaining the health and metabolism of the human body.

\section{e. Most important for human survival}

Horticulture is very useful to support the food supply in a country. The existence of horticulture will help. In developing countries, agriculture is the primary economic sector. The role and contribution of the agricultural industry in building a strong economy of a country has a critical position. This is due to several factors, as explained by Totok Mardikanto (2007), namely, the agricultural sector is a source of food supplies and raw materials needed by a country [9]. The second factor is the tremendous demographic pressure on developing countries, and the increasing income of some residents makes the need even more increasing. Third, the agricultural sector must provide the necessary factors for expanding other sectors, especially the industrial sector. These factors are usually in the form of capital, raw materials, and labor. Fourth, the agricultural sector is the base sector of important market relations and impacts the development process. Another factor is that this sector is a source of income needed for development and employment and income for the community, especially those living in rural areas.

Mr Budi also emphasized that early childhood should still be taught basics and invited to see and get to know. So that the introduction of Horticultural agriculture as basic as possible starts with basic things such as introducing vegetables, fruits, and plants that are often encountered. So horticultural cultivation is very suitable to introduce agriculture to children. Childhood is a critical period where the formation of physical skills, intelligence, and character in humans begins. Starting from simple things, the food they eat or the ingredients they usually eat that are cooked at home, such as vegetables and fruit, are very familiar to children. 
How do we learn agriculture? Starting from simple, namely cultivating plants called horticultural cultivation which has 4 types, namely:

\section{Annual Plant}

Plants that continue to grow after reproducing or completing their life cycle in more than two years, for example, breadfruit and sago.

\section{Seasonal Plants}

Crops are harvested in one crop season, i.e. 3-4 months, such as corn and soybeans or 6-8 months, such as long beans, tomatoes, corn, potatoes, and long beans.

\section{Ornamental Plants}

All plants are intentionally grown for decorative purposes or as decoration.

\section{Bio-pharmacy Plants}

Plants identified and known based on human observations have compounds that are useful for preventing, curing diseases, performing certain biological functions, and preventing insect and fungal attacks. The availability of healthy foods to herbal medicines that will benefit many people.

From the above understanding, horticulture can be concluded as a science that studies plantation plant products. There are several types of plants in the plantation including vegetables, fruits, flowers, or ornamental plants. For the type of plant as a product that is cultivated, it can be adapted to the ecology or environment around the place of cultivation.

\section{METHOD}

\subsection{Questionnaire}

I can conclude that most parents have not/rarely educated their children about agriculture. However, many know about horticultural agriculture and realize the importance of educating their children from kindergarten/PAUD to elementary school. As well as the view of activity books as literacy for the introduction of horticultural agriculture), it can conclude that many parents do not know and have never carried out activity books. On the other hand, I strongly agree if the activity book is used as an introduction to horticulture literacy.

\subsection{Interview}

Interview was conducted with Mr Budi Widodo S.P as Head of the Horticulture Section of the Department of Agriculture and Horticulture of Malang Regency for more in-depth information about horticulture. He identifies three aspects to be implemented to significantly impact the community, especially the younger generation, which will change their understanding of agriculture, which are:

1. Invite the kids to practice

2. Giving understanding to children

3. Give examples of activities for children

\subsection{Comparative Studies}

The first book, the Smart Science Book Series on Plant Life, from the aspects, described. Namely, there is no book interaction and minimal readership; this book presents visuals and procedures that are clear but less interactive. Still, science is added in terms of content about Agriculture, which is very educative and new things for children to learn. The second book, the Encyclopedia of intelligent toddlers, the Garden series, contains excellent content in introducing gardens, but the choice of very blurry colors is a bit disturbing. An exciting feature of a bonus book is that the sticker is beautiful to readers. In the third book, My First Tomato Garden Book, the drawback is the lack of text, so children will have to understand the visuals very well. However, it is exciting that the bonus tools for growing tomatoes are ready to plant tomatoes, pots, and cheers for watering plants so that reading children can directly apply them. The Smart Science Series on Plant Life has the advantages of storytelling and literacy, which are very interesting, have a good plot; this second book is more complex than other books; this book is suitable for elementary school-aged children, not suitable for kindergarten/early education children. The second book of the Encyclopedia of intelligent toddlers in the Garden series is by its target, toddlers; the content presented is very appropriate, highlighting visuals and simple explanations of how plants grow and what is in the garden so that children feel the experience of being in the garden. The third book, My first Tomato Garden, did not describe more deeply, only the practice and to the point, the delivery was made for children to practice growing tomatoes. The three books above can be used as input for designing future Activity books. The first book has advantages in story and literacy; the second book has advantages in visuals and the children's experience in the garden with bonus stickers. The third book has advantages in actual activities. Will combine these three aspects into a compilation and input for this design and research.

\section{RESULTS AND DISCUSSIONS}

The National Institute for Literacy defines Literacy as "An individual's ability to read, write, speak, calculate and solve problems at the skill level required in work, family and society. If reading is the same as seeing, then what you have is only the most basic level of literacy skills, which is just doing reading activities and knowing 
and capturing meanings to the extent that they are written. More than that, reading requires various skills that are much more complex. Visuals help learners more easily understand a message and improve memory when recalling information. Visuals can make students store and recall information, so in Gagne's information processing theory, visuals can be a stimulus that can store information in long term memory. It interests the younger generation in learning more about agriculture; it is possible to introduce children to agriculture at an early age [10]. Starting from familiarizing children with the functions and benefits of plants through books and other media, then familiarizing children with fruits and vegetables to introducing them to agriculture by inviting them to interact directly in the garden is an effort that can do to arouse children's interest in agriculture.

\subsection{Activity Book}

The hypothesis in this study is that there is a positive and significant relationship between activity books as Literacy in the introduction of horticultural agriculture. In designing this activity book, adult behavioural modelling is a powerful tool to support children's learning. There are two models (Figure 1):

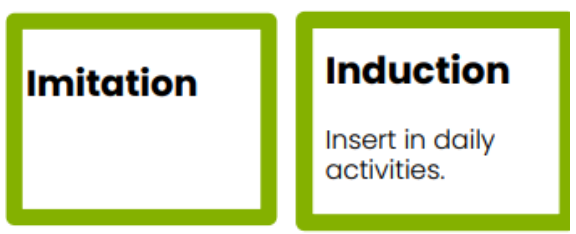

Figure 1 Imitation \& Induction

1 Imitation - children learning through their observations; and

2 Induction - children detect patterns in their experiences and construct their conceptual knowledge of the world.

The activity book titled "Together Planting Horticulture!" will be transformed into an activity book and packaged in a story. This picture book will include activities, such as mentioning the names of the plants, farming procedures, colouring, then being equipped with agricultural equipment so that children will directly interact with the book and practice farming (Figure 2).

In this design, the book will be dominated by illustrations that carry the theme of agriculture. Still, because the target market is children, It will make it as attractive as possible. Full of bright colours and children's characters that can represent them. So that this Activity Book is intended for ages 5-12 years which is for cognitive children where the age of 5-12 years includes the preoperational stage, namely being more aware of thinking concretely with the world around them and at the age of 7-11 years old being operationally resistant where children can use logic and thoughts begin to be organized.
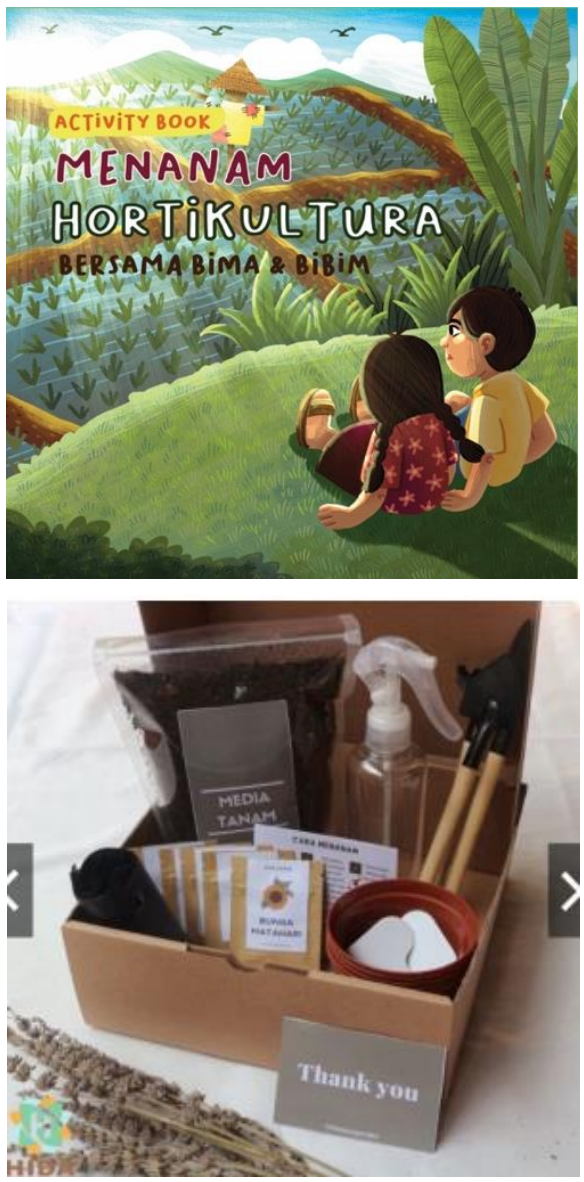

Figure 2a Activity Book: Cover (above); Figure 2b Farming Kit (below)

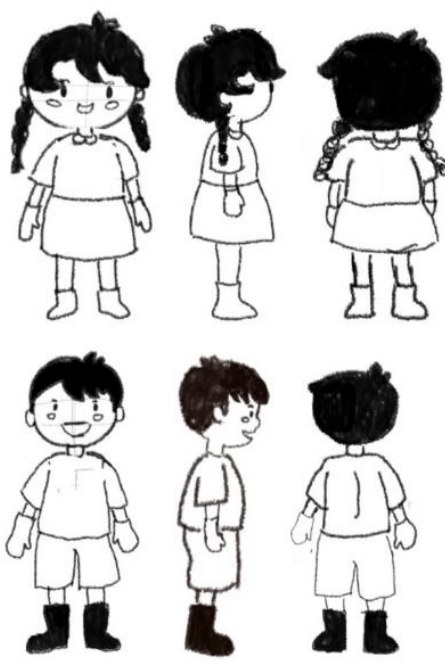

Figure 3 Main Character: Bibim (above), Bima (below)

Bima

The main character in this design is named Bima (Figure 3). An active boy from the city interested in the world of agriculture. Bima's character is described as an elementary school child around 7 years old. 


\section{Bibim}

The second character, Bibim, is Bima's younger brother (Figure 3). Bibi's character is an innocent girl who is very curious about agriculture. He wondered why his grandmother was so diligent in farming. That's where Bibim's curiosity about agriculture emerged.

This book tells the story of Bima and Bibim having a school holiday. My father and mother invited me to spend the holidays at my grandmother's house in the village. Bima and Bibim, when they got there, were invited to do agricultural activities, and from there, they liked agriculture and got how many benefits of agriculture received the many benefits of horticulture.

\section{CONCLUSIONS}

Introducing the world of agriculture from an early age, one of which starts with a basic introduction. Given that children are the nation's first-generation, it is necessary to instil a love for the environment. Starting from simple things, the food they eat or the ingredients they usually eat cooked at home, such as vegetables and fruit, are very familiar to children. Picture book with activity kit can be a suitable form for pre-school children to learn about horticulture.

\section{REFERENCES}

[1] C.J. Dunst, C.M. Trivette, T. Masiello, N. Roper, A. Robyak, Framework for developing evidencebased early literacy learning practices. Center for Ea. 2006

[2] D. Pinker, "Words and rules in the human brain," Nature, vol. 387, no. 6633, pp. 547-548, Jun. 1997.

[3] Arifin Zainal. Penelitian Pendidikan : Metoda dan Paradigma Baru. Bandung : PT. Remaja Rosdakarya; 2011.

[4] A. Rahadi. Media Pembelajaran, Jakarta : Dikjen Dikti Depdikbud; 2003.

[5] J. Witabora (2012). Peran dan perkembangan ilustrasi. Humaniora, 3(2), 659-667.

[6] L. Zeegen, Fundamentals of illustration. Fairchild Books, 2017.

[7] Piaget and Fernanda Mendes Luiz, As formas elementares da dialética. São Paulo: Casa Do Psicólogo, 1996.

[8] "Tanaman Hortikultura : Pengertian, Jenis dan Manfaatnya," Kebun.co.id, 08-May-2021. [Online]. Available: https://www.kebun.co.id/tanamanhortikultura/. [Accessed: 24-Sep-2021]

[9] Mardikanto, Totok. Sistem Penyuluhan Pertanian. Surakarta: Universitas Sebelas Maret; 2009.
[10] G. Salomon. Interaction of media, cognition and learning. San Francisco, CA: Jossey-Bass. Published again by Lawrence Erlbaum; 1994. 